\title{
Comparing The Affects Of Management Practices On Organizational Performance Between For-Profit And Not-For-Profit Corporations In Southeast Wisconsin
}

Gary F. Keller, Ph.D., Cardinal Stritch University, USA

\begin{abstract}
The need to demonstrate the effectiveness of any business or organization worthy of attracting resources and transforming them into valued products/services is an entity's primary mission. A variety of methods have evolved over time to measure a for-profit enterprise's performance. Economists have typically studied how well a firm manages the factors of production under its control while accountants and financial analysts scrutinize a variety of analytical tests to determine current and future performance. Not-for-profit organizations have adopted many of the commercial sector's economic and accounting/financial techniques to gauge their performance. However, an issue that plagues the analysis of for-profit and not-for-profit businesses is the effect that management has on an enterprise's performance. While economists and accountants can account for nearly all of the factors of production, the discipline cannot calculate the effect of management on agency performance. Considering the roles and economic impact that both forprofit and increasingly not-for-profit organizations/non-governmental organizations (NPO or $N G O)$ it is vital to assess how these organizations are managed and what if any effect management practices have on their organizational performance. The purpose of this quantitative research investigation was to study the affect of 18 management practices defined as "operations (three practices), monitoring (five practices), targets (five practices), and incentives (five practices)" (Bloom \& Van Reenen, 2007, pp. 1393 - 1397) had on the performance of for-profit firms and NPOs in southeast, Wisconsin. The basis of this research project was derived from two studies. One study (Keller, 2009) was conducted on for-profit corporations in late 2008 and the second that Keller conducted on NPOs in 2010. The examination revealed that management practices did not have a statistically significant impact on the economic performance of for-profit firms (with the exception of one ownership type) and a strongly significant influence on not-forprofit organizations.
\end{abstract}

Keywords: Management Practices; Economic Performance; Economic Measurement of Management; For-Profit Performance Measurements; Not-For-Profit Performance Measurements; Management Theory

\section{INTRODUCTION}

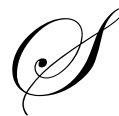

ince the Industrial Revolution in the United States (c., 1860 1890) economists, social scientists and their management science colleagues have attempted to explain why some firms thrive and others fail. Many explanations have been offered over the decades. Economists have opined that factors such as capital, technology and other inputs account for the differences between flourishing and failed firms (Bloom \& Van Reenen, 2007). Greenwald (2004) asserted that while economists have typically attributed growth in aggregate economic activity to the introduction of technology, the decision to apply new equipment and other factors of production in a systematic way is a management function. Greenwald stated that "microlevel studies at firms and even plants have consistently shown that most improvements in operating efficiency are attributable to the small, steady benefits of 
day-to-day management intervention, not to dramatic technological innovations or capital investments" (p. 3). However, a major barrier to explaining the differences between thriving and unsuccessful companies has been the absence of high-quality data that measures in a consistent way the relationship between management practices and economic performance (Bloom \& Van Reenen, 2007).

Around the world, not-for-profit organizations (NPOs) or non-governmental organizations (NGOs) are making an increasingly important contribution to national economies. In the United States in 2007 there were $1,569,572$ tax-exempt organizations accounting for $8.11 \%$ of all wages and salaries paid with $\$ 2.6$ trillion in total assets (National Center for Charitable Statistics, 2010). The demand to effectively manage this sizeable portion of America's GNP has led many NPOs to utilize many of the commercial sector's economic and accounting/financial techniques to gauge their performance.

However, an issue that plagues the analysis of for-profit and not-for-profit businesses is the effect that management has on enterprise performance. While economists can account for nearly all of the factors of production, the discipline cannot calculate the effect of management on agency performance. Similarly, accountants and financial analysts can compute the outcome of fiscal transactions; however, the professions cannot accurately attribute the effect that managerial decisions have on how the financial numbers were generated.

The type of data collected for this study was quantitative (interval and ratio scale) derived by a survey instrument that was closely patterned after one used and extensively validated by Bloom and Van Reenen (2006, 2007). The authors sought to develop an instrument that reliably calculated the connection between management practices and economic performance (Bloom \& Van Reenen, 2007). They developed an 18 question survey that investigated the quality of management practices using a Likert-type 1 to 5 rating scale. The purpose of this quantitative study was to determine whether for-profit corporations or NPO's management practices, defined by Bloom and Van Reenen (2007) as operations, monitoring, targets and incentives, were related to their economic performance defined as increases/decreases in the number of employees. This economic performance criteria was selected as a proxy for financial gain and a strategic success factor for the following reasons: a) employment data was used as a proxy for firm economic performance because privately held firms are not required to publicly file reports about their financial status in the United States; b) an NPO's primary goal is to financially break even, therefore year over year financial gain may not be a significant indicator of positive financial success, indeed a profit may be anathema to the organization; c) contributions toward an ongoing capital campaign or special project could distort an organization's financial position; d) a deficit due to special circumstances could also distort an organization's financial position; e) the gain/loss of employees provides a quantifiable insight into the entity's relative effectiveness and if the organization's products/services were in demand, constant or declining.

To accomplish the goal of studying the impact of management practices on the performance of for-profit corporations and NPOs in southeast, Wisconsin a critical review of the relevant peer-reviewed and scholarly literature was conducted. The type of data collected for both for-profit and not-for profit enterprises were quantitative (interval and ratio scale) derived by a survey instrument that was closely patterned after one used and extensively validated by Bloom and Van Reenen (2006, 2007). The author received permission from Bloom to utilize his methodology and he commented favorably on the modifications made by the author to apply Bloom's telephonic survey to a mailed survey format.

In October, 2008 a survey instrument was sent to the CEOs of 682 qualified firms in the southeast, Wisconsin. The qualified companies (682) included firms with 49 or more employees derived from the Unemployment Compensation data bases for Racine and Kenosha Counties dated September 2, 2008. The survey instrument was used to sample 100\% of the eligible population of 682 firms. In January, 2010 a survey instrument similar to the one used by the author in 2008 was sent to the chief executive officers of 100 qualified NPOs in southeast Wisconsin. The population was limited to organizations listed on the unemployment compensation data base of the State of Wisconsin and excluded governmental, religious, health care and education (school systems and colleges/universities) organizations. 


\section{LITERATURE REVIEW - FOR PROFIT PERSPECTIVE}

Since the advent of the industrial economy and its evolution into the information age, corporate leaders have searched for a succinct set of guiding principles that can both guide and measure firm performance. Prior to the Industrial Revolution (1750) the typical farmer or artisan in Europe was not much better off than their ancestors dating back to ancient Rome or Greece; however after the Industrial Revolution that situation changed dramatically (Hubbard, 2006). With the advent of factories and dramatic increases in productivity the scale of coordinating the operations of large enterprises became more difficult. With little historical precedent or academic resources to draw upon, corporate leaders groped for solutions to efficiently manage their enterprises competing in a new competitive environment.

As the American economy continued its massive growth in the later part of the twentieth century a variety of new management theories continued to emerge in popularity to systematize the efficiency and competitiveness of a firm. A variety of management theories emerged during the early period of America's industrial development Theorists from Frederick W. Taylor, The Principles of Scientific Management (1911) to W. Edwards Deming, Out of the Crisis (1986) to Robert S. Kaplan and David P. Norton, The Balanced Scorecard (1996) have attempted to capture the essence of a singular method to consistently produce corporate success. Furnham (2005) studied the evolution of contemporary management trends $(1950$ - 2000) and catalogued 24 different management approaches ranging from Empowerment to Theory Z. However; despite the best efforts of many, the search for the managerial equivalent of the Theory of Relativity, a clear definition of corporate performance measures and an explanation of the connection between management choices and corporate results continues.

Hubbard (2006) offered an intriguing insight into the mystery of why some enterprises consistently perform at very high levels and others do not. The key to unraveling the performance/productivity puzzle is assessing corporate competitiveness on a micro economic level. Hubbard cited the work of Alfred Chandler Jr. and David Landes who argued that professional management was the key factor for the United States' rise to economic prominence compared to its European rivals. "Through the microeconomic perspective, management is, at heart, a choice made by each firm" (p. 30).

A seminal study by Bloom and Van Reenen (2006) of more than 700 manufacturing firms in Great Britain, France, Germany and the United States found that the approach taken by corporate leaders was the foremost management influence on enterprise performance. Those firms with superior management were associated with higher productivity, return on equity and market capitalization. Bloom and Van Reenen (2007) followed up their study of 700 European firms with an expanded research project encompassing more than 4,000 American, European and Asian businesses. Bloom and Van Reenen (2007) research further reinforced their 2006 findings. Bloom and Van Reenen also found that there was no single management practice that provided the key to improved firm performance. Rather, it was the average score of 18 management practices grouped into "four areas: operations (three practices), monitoring (five practices), targets (five practices), and incentives (five practices)" (p. 1361) when compared to a firm's economic success that provided the most accurate indicator of success.

\section{LITERATURE REVIEW - NOT-FOR-PROFIT PERSPECTIVE}

The challenge to manage and measure the effectiveness of any organization is complex and frequently a highly subjective task. The for-profit sector created commonly accepted accounting and financial standards that indicate the economic performance of a firm. However, evaluating the utility of not-for-profit organizations (NPO) has been a historical challenge, given the sector's purpose of producing social well-being for public stakeholders compared to the for-profit's objective of producing wealth for private shareholders. As the number of NPOs increased to deal with a myriad of social issues, so did the competition for support and the need to demonstrate how NPOs utilized contributed resources. It was not long before the NPO sector adopted the commercial sector's accounting and financial gold standards to gauge institutional output.

In addition to utilizing commonly accepted financial standards, NPOs also attempted to appliqué many forprofit managerial theorems onto their institutions. But which management practice was the equivalent of a commonly accepted accounting practice? Furnham (2005) catalogued 24 different management practices ranging 
from Empowerment to Theory $\mathrm{Z}$ that were introduced in the last half century. Additionally, during the last 40 years many of the best known management theorists translated their principles for use in the charitable sector. Examples include McConkey (1973) Management by Objectives (MBO); Deming, Out of the Crisis (1986) TQM and many of its derivatives such as ISO, Six Sigma and etc.; Drucker (1990) Managing the Non Profit Organization; Buckmaster (1999) Benchmarking; Kaplan (2001) the Balanced Scorecard; Sanger (2008) and Field (2009) Data Drive Performance Measurement and Lewis (2003) a hybrid of all of the evolving management theories.

Unfortunately many commercial management theories have not always produced the best solutions for NPOs (Rojas, 2000). Speckbacher (2003) noted that one reason commercial concepts did not always succeed in the NPO sector was because the assumptions underlying the economic and organizational models were alien to the missions of many NPOs. For example, outsourcing certain functions (ex. a call center, food preparation, and security services) may save a for-profit firm a considerable sum of money but could be an operational and public relations disaster for a community based shelter for homeless or abused persons. Herman and Renz (2004) offered that "finding the right fit among (management) practices is more important than doing things the "right way" (p. 694). Herman and Renz (2008) also conducted an extensive literature review of nonprofit organizational effectiveness and highlighted nine conclusions, including one which stated that it was unlikely there were universally applicable best practices for all NPO boards and management.

A further issue that has clouded the topic of evaluating the impact that management practices have on firm or organizational performance is the lack of a precise definition of performance. Ritchie and Kolodinsky (2003) asserted that agreement about NPOs financial performance measurement and overall performance evaluation was elusive. Folan, Browne and Jagdev (2007) argued that there is no precise definition of the meaning of performance in the context of management science and as a result financial measurements continue to be the default indicators of managerial quality. Young (2007) claimed that while profitability is an unambiguous criterion for commercial ventures, no comparable standard exists for NPOs. While NPOs are required to break even, a surplus may or may not be a sign of achievement due to the nature of the organization's mission and legal (501 (c) (3) tax exempt status.

The definition of a not-for-profit organization according to the Internal Revenue Service is "An organization may qualify for exemption from federal income tax if it is organized and operated exclusively for one or more of the following purposes, religious, charitable, scientific, testing for public safety, literary and educational (IRS, 2010). There are 4 other qualifying organizational types; social welfare organizations; labor unions, farm bureaus and others; business leagues; and social and recreational clubs. To distinguish the many types of 501 (c) (3) organizations a classification system was developed, the National Taxonomy of Exempt Entities (NTEE). The NTEE is a system used by the IRS and the National Center for Charitable Statistics to classify nonprofit organizations (NCCS, 2010).

The literature was replete in demarcating management theory and financial measurements. However, few if any scholars have been able to demonstrate a connection between the two elements. The major impediment to connecting management practices to economic performance was the inability to select which management practices should be measured and correlating them to firm results. As a consequence, economists, financial analysts and accountants utilized the most reliable and acceptable measures available, fiscal ratios, balance sheets and etc. Of all of the classic factors of production, management was among the most difficult to quantify. Management was said to matter but evaluated similar to the way electrical engineers explain the impact of electricity on various system, i.e. the outcome is known; however, the exact composition of electric current remains a mystery. Bloom and Van Reenen provided a methodology and survey tool to illuminate the correlation between management decisions and firm economic performance.

\section{METHODOLOGY - FOR-PROFIT ASSESSMENT}

The problem addressed in this part of the quantitative study was investigating the economic performance of firms located in southeast Wisconsin as measured by increases and or decreases in the number of employees. Norse (1968) recommended the use of employment data as a proxy for firm economic performance because privately held firms do not have to publicly file reports about their financial condition in the United States. In this study, employment data was obtained from respondents to the survey instrument. Below is the null and alternative 
hypothesis that guided this study.

H10. There is no difference in firm economic performance based on management practices of corporations located in southeast Wisconsin.

H1a. There is a difference in firm economic performance based on management practices of corporations located in southeast Wisconsin.

The type of data collected was quantitative (interval and ratio scale) derived by a survey instrument that was closely patterned after one used and extensively validated by Bloom and Van Reenen $(2006,2007)$. On October 23, 2008 a survey instrument was sent to the CEOs of 682 qualified firms in southeast, Wisconsin. The qualified companies (682) included firms with 49 or more employees derived from the Unemployment Compensation data bases for Racine and Kenosha Counties dated September 2, 2008. The survey instrument was used to sample 100\% of the eligible population of 682 firms. The response rate to the mailing of the survey was 54 surveys or a response rate of $7.92 \%$. This rate was considered acceptable for a blind direct mail survey with no built in system for followup except for a letter of reminder to the entire population of 682 .

In this part of the study a number of Student T-Ratios and a series of ANOVA tests were conducted to test the four null hypotheses. Null hypothesis 1 was analyzed using the ANOVA test. The data analyzed ownership type by the ANOVA test. Furthermore hypotheses 2 and 3 were analyzed using a Linear Regression Analysis. The correlations resulting from these analyses for null hypotheses 2 and 3 were further analyzed using the Student TRatio. A .05 level of significance was used to determine the significance for each of the null hypotheses.

\section{METHODOLOGY - NOT-FOR-PROFIT}

The purpose of this portion of the quantitative research investigation was to study the impact of 18 management practices defined as "operations (three practices), monitoring (five practices), targets (five practices), and incentives (five practices)" (Bloom \& Van Reenen, 2007, pp. 1393 - 1397) on the performance of NPOs in southeast, Wisconsin. In this research project, employment data was requested of respondents to the survey instrument. The type of data collected was quantitative (interval and ratio scale) derived by a survey instrument the author used in a study (Keller, 2009) conducted of the for-profit sector in southeast, Wisconsin.

Below is the null and alternative hypothesis that directed the analysis of not-for-profit organizations.

H10. There is no difference in the organizational performance based on management practices of NPOs located in southeast Wisconsin.

H1a. There is a difference in organizational performance based on management practices of NPOs located in southeast Wisconsin.

On February 9, 2010 a survey instrument was sent to the Executive Directors of 100 qualified NPOs in southeast, Wisconsin. The qualified NPOs (100) included those derived from the Unemployment Compensation data bases for Racine and Kenosha Counties. The survey instrument was used to sample 100\% of the eligible population of 100 organizations excluding governmental units, schools, health care agencies and colleges/universities. The data was analyzed using a Student T-Test to determine whether to accept or reject the null hypothesis. A Student T-Test was selected to analyze the data due to the small sample size (Zikmund, 2003). A .05 level of significance was used to determine significance. The Student T- Test measured whether if employment growth as the indicator for organizational performance was significant.

\section{METHODOLOGY - COMPARING NOT-FOR-PROFIT FIRMS WITH NOT-FOR-PROFIT ORGANIZATIONS}

A series of ANOVA tests were conducted to compare the results of the 18 management practices tested in the surveys sent to for-profit firms and not-for-profit organizations located in southeast Wisconsin, USA. A .05 level of significance was used to determine the significance of each factor that was compared. 


\section{FINDINGS - FOR-PROFIT FIRMS}

The researcher used an ANOVA One-Way test to determine whether to accept or reject Hypothesis 1: There is no difference in the organizational performance based on management practices of NPOs located in southeast Wisconsin. With an F Value of .69 the researcher was unable to reject the Null Hypothesis (P value of .40) at the .05 level. The ANOVA One-Way Test for Hypothesis 1 indicated that for all ownership types $(N=53)$ the null hypothesis is accepted. However, a more thorough analysis of the data revealed that several significant correlations exist at the .05 level between economic performance and specific ownership type management practices. The analysis indicates that there is a significant difference $(p=.007)$ in the management practices used in family owned firms and the economic performance of these firms. Additionally with a Significance $F$ of .01 the null hypothesis was rejected and the research hypothesis was accepted that there is a difference between the management practices and economic performance of privately owned firms. It should be noted that both family and privately owned firms were combined in this analysis because both types of firms are defined as privately owned firms.

\section{FINDINGS - NOT-FOR-PROFIT ORGANIZATIONS}

In January, 2010 a survey composed of 15 general organizational identifier questions and 18 management practices was sent to the chief executive officers of 100 qualified NPOs in southeast Wisconsin. The response rate to the mailing of the survey was 20 surveys or a response rate of $20 \%$. in this study.

The researcher used a Student T-Test to determine whether to accept or reject the null hypothesis for NPOs

H10. There is no difference in the organizational performance based on management practices of NPOs located in southeast Wisconsin.

H1a. There is a difference in organizational performance based on management practices of NPOs located in southeast Wisconsin.

The Student T-Test measured whether employment growth as the indicator for organizational performance of respondents' organizations was significant. The Student T-Test result was (10.26) which was strongly significant at .01 level (.0000002.85) level. This unusually small P value was sufficient to reject the Null Hypothesis and accept the Alternative Hypothesis: There is a difference in organizational performance based on management practices of NPOs located in southeast Wisconsin. In aggregate, $70 \%$ of the organizations who responded to the survey reported no change in employee count $(35 \%)$ or increases of between $1 \%$ to $10 \%$ or greater $(35 \%)$ in the number of employees.

\section{FINDINGS - COMPARISONS BETWEEN FOR-PROFIT AND NOT-FOR-PROFIT ENTERPRISES}

The researcher used a series of ANOVA Single Factor tests to compare the responses of for-profit firms and not-for-profit organizations to the questions regarding 18 management practices. The results indicated that statistically significant differences existed in 4 (which is $22 \%$ of the management practices) at the .10 level of significance, see Table 1. They were:

Summary for Comparison of All Management Practices - There was no statistically significant difference between the management practices of for-profit and not-for-profit entities.

Factor 1: Modern Workflow Systems - For-profit firms use better workflow systems (e.g., ISO standards, Just In Time Inventory, lean manufacturing, automation, total quality management, Six Sigma, automation, flexible manpower, support systems, attitudes and behavior) than NPOs.

Factor 6: Corporate Performance Dialogue - How Information is Used in Meetings - NPOs used information to make decisions better than for-profits. 
Factor 14: Rewarding High Performance - For-profits were able to award performance related rewards better than NPOs.

Factor 18: Retaining Talent - For-Profit firms were able to provide compensation/benefits better than NPOs.

Table 1

Comparison of 18 Management Practices

\begin{tabular}{|l|c|c|}
\hline 18 Management Practices & $\boldsymbol{A N O V A}$ & P-value \\
\hline Summary of All Data: For-Profit v. NPO & $\boldsymbol{F}$ & .176 \\
\hline 1. Modern Workflow Systems & 4.07 & .047 \\
\hline 6. Corporate Performance Dialogue & 3.31 & .074 \\
\hline 14. Rewarding High Performance & 3.72 & .057 \\
\hline 18. Retaining Talent & 6.69 & .011 \\
\hline
\end{tabular}

An evaluation of how for-profit firms and not-for-profit organizations ranked the 5 factors (financial resources, employees, management practices, materials and technology) that were vital to enterprise success was revealing. Depicted in Table 2 is the comparison ( $1=$ low, $5=$ high) of the five vital success factors.

Table 2

Comparison of 5 Vital Success Factors

\begin{tabular}{|l|c|c|}
\hline \multicolumn{1}{|c|}{ 5 Vital Success Factors } & For-Profit & Not-For-Profit \\
\hline Financial Resources & 1 & 1 \\
\hline Employees & 2 & 4 \\
\hline Management Practices & 5 & 3 \\
\hline Materials & 3 & 2 \\
\hline Technology & 4 & 2 \\
\hline
\end{tabular}

\section{ANALYSIS OF FOR-PROFITS' RANKINGS}

Most respondents to Keller's 2008 survey indicated that they had adequate access to capital. The importance of financial resources receiving a relatively low grade (number 1 or low) for its significance to the firm's success may be explained by the response to Question 14 (Does the firm have access to capital?) where 93\% of respondents stated they had access to capital. In essence respondents may take for granted their ability to secure adequate amounts of capital to operate their firms. Respondents may take for granted that their firm either has accumulated a sufficient amount of saved capital or have relatively easy access to it. There was agreement regarding the top two vital success factors (technology and materials). One of the reasons firms graded technology and materials as the top factors may be related to the fact that key business decisions are made at a distant corporate headquarters which delegates strategic decisions to local managers for implementation. The impact of employees on firm performance received a mixed response from respondents to the study's survey. Of the respondents ranking employees as vital to the success of their firms, 55\% ranked it high (3-5) while a slightly lower number $47 \%$ considered employees as being a low success factor for their firms' success. Clearly, the role that employees play in the performance of firms in southeast Wisconsin is somewhat split due to the difference in firm ownership. The final vital success factor that was ranked was technology. Of the respondents ranking technology as vital to the success of their firms, $77 \%$ ranked technology high (3-4-5) while 23\% considered technology low. Respondents' rankings of the importance of materials and technology to their firms' success was quite high indicating that most firms desire to stay abreast of tools and techniques that will keep their firms efficient and productive. Management practices, the independent variable in this study, was selected by for-profit firms as the most vital factor to their enterprises' success. This high ranking was revealing. Four of the five vital success factors (sans management practices) are the fundamental components that economists use to assess the performance of a firm. The respondents to the 2008 survey affirmed Greenwald, Bloom and Van Reenan's thesis that management choices (the effect of management) are measureable and can be directly linked to the economic performance of a company. 


\section{ANALYSIS OF NOT-FOR-PROFITS' RANKINGS}

At first glance, the not-for-profit respondents' ranking of the success factors was somewhat surprising considering the missions of NPO. One explanation for the curious ordering of materials being the most important success factor may reflect the diversity of organizations in the survey sample (from an adult literacy group to a municipal zoo) and a growing trend in NPO agencies, social entrepreneurship. Many NPOs are attempting to generate earned revenue via creation of products/services that provide a new revenue stream to diversify away from dependence on contributions, funding from United Way type funding agencies and fees for services which oftentimes do not fully recover the services' costs. The ranking of management practices by respondents as the third most vital success factor is curious given the strongly significant correlation of management practices and organizational performance. One explanation for this ranking may be an increasing managerial skill level and sophistication of not-for-profit corporate leadership. This phenomenon may be a result of the inclusion of talented for-profit leaders serving on the boards of directors of NPOs and the growing trend of NPO executives securing management degrees and ongoing training.

\section{IMPLICATIONS}

This research study sought to determine if there are significant differences between the management practices and enterprise performance between for-profit firms and NPOs located in southeast Wisconsin. It was found that on the whole there was no statistically significant difference between the management practices and firm performance among the for-profit population, with the exception of one key ownership group (family and privately owned firms). Additionally, it was found that for-profit firms ranked management practices as the top corporate vital success factor.

A review of the data for not-for-profit organizations showed that management practices were correlated to organizational performance. Despite the strongly significant statistical correlation between management practices and organizational performance, NPO respondents did not rank management practices as the number one success factor for their agencies. As mentioned previously, this disparity may represent a growing trend in the evolution of the management practices of NPOs.

Both components of this study were conducted while the American economy was in the worst part of recession of 2008-2010. While some for-profit firms added employees, most were decreasing head counts. NPOs also reported mixed results in terms of significant declines in revenue derived from operations; however what greatly stabilized their operations was the increase in donations.

In the final analysis, this study needs to be repeated on a semi-annual basis to achieve two important results; generating a larger number of responses and creating a base line to compare and improve the robustness of the research design and the practical use of the results. As noted several times, the requirement to generate "numbers" that demonstrate the quality of an enterprise has taken a life onto itself in both the for-profit and not-forprofit sectors. Management practices are frequently considered "soft skills" and therefore not a reliable, countable and important "asset." It is refreshing to discover that the NPO sector and family and privately held corporations in this study demonstrated that management practices have a "hard impact" on the bottom line.

\section{AUTHOR INFORMATION}

Gary Keller earned his Ph.D. in Business with a specialty in Management from Northcentral University. Keller also possesses Masters degrees in History and Management. Keller is a tenured Associate Professor in the College of Business and Management (specializing in adult degree completion programs ASB - MBA) at Cardinal Stritch University in Milwaukee, Wisconsin. 


\section{REFERENCES}

1. Bloom, $\mathrm{N}$ and Van Reenen, $\mathrm{J}$ 2006, Measuring and explaining management practices across firms and countries. Retrieved February 1, 2008 from http:cep.lse.ac.uk/textonly/people/bloom/papers/BloomVanReenen2.pdf.

2. Bloom, N and Van Reenen, J, Dorgan, S, Dowdy, J 2007, July, "Management practice and productivity: Why they matter", Management Matters, McKinsey \& Company and the Centre for Economic Research.

3. Bloom, N and Van Reenen, J, 2007, November, Measuring and explaining management practices across firms and countries. Quarterly Journal of Economics, vol. 122, no. 4, pp. 1351-1408.

4. Buckmaster, N, 1999, Benchmarking as a learning tool in voluntary non-profit organizations. An exploratory study. Public Management (1461667X), vol. 1, no. 4, pp. 603-616.

5. Deming, WE, 1986, Out of the crisis: quality, productivity, and competitive position. New York: Cambridge University Press.

6. Drucker, P, 1990, Managing the non-profit organization; practices and principles. New York, NY: HarperCollins.

7. Field, C, 2009, Performance management. Financial Management (14719185), pp. 40-41.

8. Folan, P, Browne, J, \& Jagdev, H, 2007, September, Performance: Its meaning and content for today's business research. Computers in Industry, vol. 58, no. 7, pp. 605-620.

9. Furnham, A, 2005, The psychology of behaviour at work. London: Psychology Press.

10. Greenwald, B. 2004, Winter. "The good life: How managers made the modern world", Hermes, Retrieved January 8, 2008 from http://www2.gsb.columbia.edu/hermes/winter2004/article greenwald.cfm.

11. Herman, R, \& Renz, D, 2004, Doing things right: Effectiveness in local nonprofit organizations, a panel study. Public Administration Review, vol. 64, no. 6, pp. 694-704.

12. Herman, R, \& Renz, D, 2008, Advancing nonprofit organizational effectiveness research and theory: Nine theses. Nonprofit Management \& Leadership, vol. 18, no. 4, pp. 399-415.

13. Hubbard, G, 2006, The productivity riddle. Strategy and Business, vol. 45, pp. 28-33.

14. IRS, 2010, Publication 557, 3., Section 501(c)(3) Organizations. Retrieved from http://www.irs.gov/publications/p557/ch03.html\#d0e3190

15. Kaplan, R, 2001, Strategic performance measurement and management in nonprofit organizations. Nonprofit Management \& Leadership, 11(3), 354.

16. Keller, G, 2009, Do management practices affect the economic performance of

17. firms located in southeast Wisconsin, USA? International Review of Business Research Papers, vol. 5, no. 6, pp. 79-89.

18. Lewis, D, 2003, Theorizing the organization and management of non-governmental development organizations. Public Management Review, vol. 5, no. 3, pp. 325-344.

19. McConkey, D (1973). Applying management by objectives to non-profit organizations. SAM Advanced Management Journal (00360805), vol. 38, no. 1, p. 10.

20. National Center for Charitable Statistics, 2010, Quick facts about nonprofits. Retrieved May 1, 2010, from http://nccs.urban.org/statistics/quickfacts.cfm

21. National Center for Charitable Statistics, 2010, National taxonomy of exempt entities. Retrieved May 2, 2010 from http://nccs.urban.org/classification/NTEE.cfm

22. Norse, H,1968, Regional economics: A study in the economic structure, stability and growth of regions. New York: Mc-Graw-Hill.

23. Ritchie, W, \& Kolodinsky, R, 2003, Nonprofit organization financial performance measurement: An evaluation of new and existing financial performance measures. Nonprofit Management \& Leadership, vol. 13, no. 4, p. 367.

24. Rojas, R, 2000, A review of models for measuring organizational effectiveness among for-profit and nonprofit managers. Nonprofit Management \& Leadership, 11(1), 97.

25. Sanger, M, 2008, From Measurement to management: Breaking through the barriers to state and local performance. Public Administration Review, vol. 68, no. 6, pp. S70-S85.

26. Speckbacher, G, 2003, The economics of performance management in nonprofit organizations. Nonprofit Management \& Leadership, vol. 13, no. 3, p. 267.

27. Young, D, 2007, Financing nonprofits, putting theory into practice. Lanham, MD: Alta Mira Press.

28. Zikmund, W, 2003, Business research methods. Mason, OH: South-Western. 


\section{NOTES}

